\title{
THE CLASSICAL ASSOCIATION OF SOUTH AFRICA: FEBRUARY 1981 - JANUARY 1983
}

\author{
W J Henderson (University of Johannesburg)
}

\begin{abstract}
This article continues the history of the Classical Association of South Africa as recorded in the archives of the Association. ${ }^{1}$ Since the publication of the previous accounts, an important study has appeared, which reconstructs some of the political, social and cultural contexts in which the activities of the Association, as reflected in my archival reports, were imbedded. I refer to Michael Lambert's book, The Classics and South African Identities (2011). Lambert's work now adds flesh on to the bare bones of the archival material. $^{2}$
\end{abstract}

\section{Administration, February 1981 - January 1983}

\subsection{General}

The new Secretary, Prof Bruwer, informed the Executive that, in accordance with a decision by the previous conference, three persons had been nominated from universities which awarded Law degrees for which only one year of university Latin (i.e. without Matriculation Latin) was required, to advise the Executive regarding this matter. Prof Lubbe was nominated to report on Unisa, Pretoria, Rand Afrikaans, Witwatersrand and Potchefstroom; Prof Drijepondt on Orange Free State, Rhodes, Port Elizabeth, Natal and Fort Hare; and Prof Snijman on North, Zululand, Western Cape and Durban-Westville. ${ }^{3}$

Subscription fees were raised from R10 to R15 (Full Members) and from R4 to R5 (Associate Members). ${ }^{4}$ Prof Atkinson, the Treasurer, suggested to the Executive that the membership list be computerised in order to alleviate the laborious and time-consuming procedure of addressing envelopes. This would entail 'getting the list onto machine-readable cards from which sticky labels could be printed' as needed. The cost would be approximately R5 per 1000 labels and an

For the earlier articles, see Henderson 2004, 2005, 2006, 2007, 2008, 2010, 2013. For the name changes of provinces, cities and universities, see Henderson 2004:89 n. 3 (Rhodesia, Orange Free State, Rand Afrikaans University); 2005:109 n. 1 (University of Natal, South West Africa); 2006:135 n. 6 (University for Christian Higher Education, Potchefstroom), 138 n. 26 (University of Zululand); 2007:109 n. 59 (Port Elizabeth).

2 See the review by Claassen and Atkinson 2012.

$3 \quad$ S to Lubbe, Drijepondt, Snijman, 12 February 1981.

4 T to members, 9 February 1981; S to members, 17 March 1981. 
initial run of 10 labels per member was proposed. ${ }^{5}$ Another glimpse into the technological problems of the time is the printing of new letterheads and envelopes; the block bearing the emblem had to be found, or a new one made which would raise the cost to R45 for 1000 envelopes. ${ }^{6}$ It was decided to incur the expense of a new block. ${ }^{7}$ A proposal by the Treasurer for the transfer of R1 000 from the savings account to the indefinite period paid-up share account was approved by the Executive. ${ }^{8}$

Dr Coleman informed the Chairperson that Dr Michael Winterbottom (Worcester College, Oxford) would be visiting UCT in August 1983 and asked whether any of the northern universities would be interested in arranging seminars and lectures by him during his stay in South Africa. ${ }^{9}$ Prof Kriel expressed keen interest and would notify colleagues. ${ }^{10}$

Information concerning the possibility of establishing a South African Academic Centre in Rome was circulated to departments of Architecture, Art, History of Art, Music, Linguistics, Law, and Romance Languages at all South African universities. ${ }^{11}$

\subsection{Colloquium}

The conference's decision to hold a Colloquium every alternate year, between the national conferences, was now implemented. The Colloquium was to focus on the teaching of Greek and Latin at school and university. A circular announced the arrangements for the first Colloquium to be held at the University of Cape Town in 1982, with as its main theme the teaching of introductory courses in Greek and Latin at university. Possible dates suggested were 19-21 or 21-23 April, or somewhere between 28 June and 19 July. Papers were invited on the following suggested topics: the problems created by students' inadequate knowledge of their mother tongue; the pronunciation of Greek and Latin (and whether it mattered); the computer as educational tool (including a demonstration of the Plato system in use at the University of the Western Cape); the role of elementary language courses in university curricula; introductory courses (e.g. Latin for Law students; Greek for Theology students); and critical discussions of the Cambridge Latin Course and the

T to C, 15 February 1981.

S to Henderson, 9 July 1981.

Henderson to S, 30 July 1981.

T to Executive, 23 February 1982.

Coleman to C, 25 October 1982.

C to Coleman, 11 November 1982.

Kriel to Henderson, 11 February 1981. 
Greek Course, Reading Greek, of the Joint Association of Classical Teachers. ${ }^{12}$ The organiser, Prof Atkinson, outlined the programme, encouraged young lecturers to attend, invited short contributions on the teaching of the elementary courses, set the date (21-23 April), suggested that school teachers would also find much of value, and explained the need to devote time and effort to the elementary and first-year courses to ensure the future of Classics in a changing South Africa. ${ }^{13}$

On 21 April 1982, CASA members attended a cheese-and-wine party at the Irma Stern Museum to welcome delegates to the Colloquium on the teaching of first-year Greek and Latin courses at university. ${ }^{14}$

\subsection{Acta Classica}

Between Vols. XXII (1979) and XXIII (1980) a backlog of R2 400 had developed as a result of two volumes appearing in the same year. Members of the Editorial Board were obliged to pay the publisher by means of a personal loan to the journal. As proposed at the AGM in January $1979,{ }^{15}$ a request was made by Proff Gonin and Naudé to the Human Sciences Research Council for an interim grant of R3 500 to be used as a reserve fund, but this was rejected. ${ }^{16}$ Prof Naudé then approached the Executive Committee for the amount, explaining that a cheaper printing method was envisaged in which, instead of the lead-casting process, the text would be reset by the printer with lines 'unjustified' ${ }^{17}$ The Executive Committee decided to use the unprofitable nest-egg investment to bail the journal out and to justify the payment at the next conference as a matter of priority. ${ }^{18}$ By June 1982 the number of journals received in exchange for Acta Classica was $58 .{ }^{19}$

\subsection{School and university texts}

Dr Coleman raised the possibility of a collaborative effort to produce a textbook for Latin I to replace the 'tattered Kennedys' and individual study material generated at the universities. A committee could be set up to draft guidelines and

\footnotetext{
12 Atkinson circular, 18 June 1981.

13 Atkinson 1981. Some of the papers were published in Akroterion 27.3 \& 4.

14 Mezzabotta 1983:39.

15 Acta Classica report, par. 5(a).

16 H L Gonin and C P T Naudé to the President, HSRC, 2 December 1980; A J Venter, p.p. Vice-President HSRC to Naudé, 24 February 1981; Naudé to Vice-President, 2 March 1981. The annual grant of R2 000 attached to a particular volume was, however, continued.

17 Naudé to C, 9 March 1981.

$18 \mathrm{C}$ to Executive, 13 March 1981.

19 Hasse 1982.
} 
one or two full-time academics could be commissioned to write the book, perhaps funded by the HSRC. ${ }^{20}$ Prof Kriel agreed on the advisability of such a project, but pointed out that five of the universities taught Latin through the medium of Afrikaans, that the number of students taking Latin I was too small to interest a publisher unless the book was prescribed at all the universities, and that the HSRC was unlikely to fund such a venture. The matter would, however, be referred to the Executive. ${ }^{21}$ The matter was duly discussed by the Executive and referred to the forthcoming conference. ${ }^{22}$

\subsection{FIEC}

Prof Hendrickx reported that, after a short interruption, our affiliation to FIEC had been restored. He explained that FIEC was an international body to which, in principle, all national Classical associations belonged, and which worked together with other international bodies such as UNESCO. Its Annual General Meeting, attended by representatives of the national associations, took decisions concerning, in particular, the support of the publication of series, the organisation of international conferences, intercultural activities and international co-operation in the field of research on Classical antiquity. At the time, FIEC was subsidising the following publications: L'année philologique, Thesaurus Linguae Latinae, Archives photographiques de papyrus, Actes du 7 e Congrès F.I.E.C. (Budapest) and Berichtigungsliste der griechischen Papyrusurkunden. The next General Meeting was to be held in Helsinki from 27 to 29 August 1982, during which a colloquium on 'Equality and inequality among people in ancient thought' would be held. The conference after that was due to take place in Dublin on 25 August to 1 September 1984.

Prof Hendrickx proceeded to give the following reasons for maintaining membership of FIEC:

1. As in other areas (such as sport, politics, culture), South Africa had to resist isolation and try to keep its international participation.

2. By our contribution to FIEC we also assisted in the support of basic works such as L'année philologique.

3. Via FIEC the Association regularly received information and invitations regarding Classical conferences in other countries.

\footnotetext{
20 Coleman to C, 25 October 1982.

21 C to Coleman, 11 November 1982.

22 S circular, 19 November 1982, item 11; 9 December 1982, item 11.2(b).
} 
4. We can and should make our own research known to the rest of the world.

It was a regrettable fact that in the past we seldom or never made use of the chances offered us and it was necessary in future to participate as much as possible in the meetings and activities of FIEC, as its secretary, Prof F Paschoud, himself had suggested. Finally, the delegates' attention was drawn to the celebration in Italy during 1981 and 1982 of the bimillenium of Vergil's death. ${ }^{23}$

\subsection{Latin and Law}

The Secretary informed the members of the Executive and of the Sub-Committee for the Latin component of the LL.B course that Justice Van Heerden of the Natal Division of the Supreme Court had, on 14 September 1981, ruled that a student, T Barnard, could be admitted as an advocate although he held the LL.B from Unisa with Latin Special (i.e. without matriculation Latin). The Dean of the Law Faculty at Unisa defended the traditional interpretation that the phrase 'at least one course in the Latin language' in article 3(2)(a)(ii) of the Law on Advocates meant a postMatriculation course in Latin (i.e. Latin I). This was, however, rejected by Justice Van Heerden, who pointed out that the one-year university course in Latin (Latin Special at Unisa and Latin 1B at Natal) had already been accepted in the case of several applicants by the Natal Bar Council as fulfilling the requirement of the law.

A similar application was made in the Transvaal. The Secretary requested comment and guidance on possible action by CASA. ${ }^{24}$ In the end, Prof Kriel was asked to inform the Transvaal Bar Council of the Association's position..$^{25}$ Prof Kriel reported that the Pretoria Bar, represented by three advocates, intended to oppose the application of two 'Latinless' LL.Bs to be heard on 1 September before a full bench of three judges. He himself submitted an affidavit in which he set out his university's understanding and application of Article 3(2) (a) (ii) of the Law on the Admission of Advocates, No.74 of 1964, which came into effect in $1966 .{ }^{26}$ In a circular to members of the Executive in November the Chairperson reported that the judges had failed to reach agreement. ${ }^{27}$

\footnotetext{
23 See Hendrickx 1981. For a report on the World Congress on Vergil, see Ronca 1982.

24 S circular, 17 February 1982.

25 S to Henderson, 10 March 1982.

26 C to S, 20 August 1982, item 10, with a copy of the affidavit attached.

27 C to Executive, 19 November 1982, item 11. For further developments, see Van Stekelenberg 1982.
} 


\subsection{School Latin}

A request was received from the Joint Matriculation Board for commentary on the syllabus. Mrs Betine van Zyl Smit agreed to comment on the content on behalf of the Association. ${ }^{28}$ The reports of the Human Sciences Research Council on the position of Latin as a school subject were expected in 1982 or 1983.

\section{$1.8 \quad$ Next conference}

The next conference, on the 25th anniversary of the Association, was to be held at the University of Pretoria, ${ }^{29}$ with 'Greek and Roman Comedy' as the theme. ${ }^{30}$ The Secretary sent out a circular announcing the conference; papers were invited on both the main theme and other topics, papers were to be limited to 35 minutes and shorter communiqués to 15-20 minutes, and the principle of first come, first served would apply. ${ }^{31}$

The Secretary circulated a working document compiled after discussions with the Chairperson and Treasurer to the Executive. The main points raised were that (1) an address by the Chairperson should become standard practice, unless a distinguished classicist from abroad was available; (2) the Chairperson should have the freedom to speak on a specialist topic aimed chiefly at the delegates or on a topic of general interest for the wider public; (3) one of the evenings should be of such a nature as to attract the general public; (4) the local branch of CASA should act as host for this evening, handle publicity and refreshments, and encourage as many of its members as possible to attend; (5) new speakers, who might be intimidated by the 'monolithic' structure of the conference programme, which tended to present the same core of speakers each time, should be solicited; and (6) registration fees should be paid by all conference delegates (as decided at the previous conference) and an ad hoc fee by non-members attending individual sessions or papers.

Members of the Executive were to exchange ideas and comments by correspondence, since the costs of meeting were prohibitive. ${ }^{32}$ The members responded positively to the suggestions, and preliminary planning for the conference began. A conference fee of R7 was to be levied and preferably paid in advance; this would cover teas, an excursion, transport from the airport and

\footnotetext{
28 S to Executive, 13 September 1982, item 9.

29 Minutes of First Business Meeting, 20 January 1981, §5.2.

30 Minutes of Second Business Meeting, 23 January 1981, §4.

31 S general circular to all members, 1 March 1982.

$32 \mathrm{~S}$ to Executive, 22 July 1982.
} 
attendance at individual sessions. ${ }^{33} \mathrm{~A}$ second circular regarding the conference duly went out. ${ }^{34}$ An Executive 'meeting by correspondence' also dealt with various matters, including those for the business meetings of the conference. ${ }^{35}$

Concern was expressed about the fact that fewer than half of Latin teachers who had replied to a questionnaire ( 81 out of 167 ) were members of CASA. ${ }^{36}$

\subsection{Regional branches}

\subsubsection{Eastern Cape (Grahamstown) Branch}

In a letter to the Secretary, Dr K Matier reported on the Grahamstown Branch and gave formal notice of the intention to disband this branch. He explained that, after discussing the matter with Prof Gain, he had visited each of the schools in Grahamstown where Latin was taught to ascertain the wishes of the teachers. The teachers unanimously preferred the status quo where lecturers from the university visited the schools and pupils visited the university to see the Museum or attend functions such as the annual Symposium for Teachers, which attracted teachers from all over the Eastern Cape and Border. There was among the teachers 'no enthusiasm whatever for reviving the Grahamstown Branch', ${ }^{37}$

In her reply, the Secretary expressed appreciation for the ways in which the Grahamstown members were promoting the interests of Classics and noted that the Executive would assume that the branch was disbanded until its revival sometime in the future. It was pointed out to Dr Matier that (1) the life of the Association centred in the activities of the regional branches and not in the national conferences, and that permanently disbanding the Grahamstown Branch would be 'like amputating a limb'; (2) teachers should be encouraged to join CASA so that they could receive Akroterion, which specifically catered for the interests of Latin teachers; and (3) other sections of the community (students, the public) should be involved in the activities of the local branch. ${ }^{38}$

33 Henderson to C, 4 August 1982; C to S, 20 August 1982; S to Executive, 13 September 1982; 19 November 1982.

34 Circular, 28 October 1982.

35 S to Executive, 3 December 1982.

36 C to Executive, 19 November 1982. The figures were: 30 out of 51 in the Transvaal; 24 out of 45 in the Cape Province; 9 out of 18 in the Orange Free State; 2 out of 9 in Natal; 1 out of 1 in South West Africa; 0 out of 2 in National Education; 0 out of 2 in Indian Education; 9 out of 18 in subsidised private schools; and 6 out of 20 in non-subsidised private schools.

37 Matier to S, 16 February 1981.

$38 \mathrm{~S}$ to Matier, 6 March 1981. 
Although the branch had formally ceased to exist, teachers and lecturers continued to have meetings. At a Latin Teachers' Symposium, held on 19 March 1982 in Grahamstown, Mr R H Hall (English Department) gave a talk on 'Virgil and English literature'. ${ }^{39}$

\subsubsection{Natal Branch}

The Natal Branch suffered the loss of two respected colleagues, who served the cause of Classics in South Africa well: Prof Magnus Henderson died suddenly in $1981,{ }^{40}$ and Prof Farrer passed away on 24 August 1982. ${ }^{41}$

\subsubsection{Orange Free State Branch}

This branch came up with the excellent idea of making and selling a lapel badge depicting an eagle within a wreath and the letters SPQR underneath, done in black and gold against a dark red background. The badge would be sold to pupils, teachers, students and lecturers. ${ }^{42}$

\subsubsection{Transvaal Branch}

The Committee for 1982 consisted of Mr De Villiers (C), Dr Mans (VC), Mr Mader (ST), Mr C M Jooste (University of the North), Mrs B Van Zyl Smit (RAU), Dr A G P van der Walt (Potchefstroom University), Dr M Scott (Wits), Mr G J Mader (Unisa), Miss H Möller and Mrs S Nel (Afrikaans schools), Mr F Barnicoat and Mrs S Harris (English schools) and Mrs F Lonstein (Private schools). A Teachers' Conference was held on 20 March 1982, at which papers were read by $\mathrm{Mr} \mathrm{J}$ Swanepoel on 'Die mites rondom die val van Troje' and Dr Scott on 'The Roman administration of Sicily, with special reference to Verres'. On 15 June the annual reading competition took place at Saheti School. While the adjudication of the reading was taking place, pupils of the Rivonia Primary School, under the direction of Mrs Marcelle Pincus, entertained the audience with 'The horse of Troy', a pop-style cantata by E Withams, a rendering of Tennyson's 'To Virgil', and 'The rider at the gate'. Twenty-eight pupils participated in the competition. There were also a model-building competition of the Roman forum and posters of the fall of Troy. The former attracted 30 entries and the latter 20.

\footnotetext{
$39 \quad$ Hall 1982.

40 See the tribute in Akroterion 26.3 (1981) 1-3.

41 See the obituary, Akroterion 27.3 \& 4 (1982) 160.

42 DJ Coetzee to Henderson, 4 August 1982.
} 
The AGM was held on 25 September 1982. The composition of the new committee remained the same, except for Mr A F Basson who replaced Mrs Van Zyl Smit, and Mr T Rapke who replaced Dr Scott. The following papers were delivered: "n Inleiding tot die Bucolica van Vergilius' (Prof D M Kriel) and 'Some thoughts on a central theme in the Georgics' (Prof I Ronca). Prof G Monaco (University of Palermo), who was visiting South Africa, was indisposed and unable to read a paper entitled 'Vergil on sport and competition: Aeneid 5'. ${ }^{43}$

\subsubsection{Western Cape Branch}

The 1981 academic year began with an event to raise funds for Rag 1981 and create a memorable event to publicise Classics. A marathon reading of Homer's Odyssey was performed on the steps of Jameson Hall by students drawn from the Classics, Drama, Education and English departments or faculties. After a Greek prayer and a libation, each reader, dressed in a chiton, leaning on a rhapsode's staff and standing on a podium, read one book, in a continuous relay, starting at 13:00 and lasting 16 hours. At sunset, Book 10 was read by the distinguished actor Michael Atkinson. ${ }^{44}$ At a Teachers' Meeting held on 4 February 1981, Prof Baumbach spoke on the historical evidence for the pronunciation of Latin, and Mrs Mezzabotta demonstrated an approach to an appreciation of a prescribed passage of the Aeneid. Mr L X Munnik, Director of the Teachers' Centre, was thanked for his assistance in organising and hosting the meeting at the Centre in Mowbray. ${ }^{45}$ On 11 April 1981, Mrs B Millar initiated the members of the audience in the Computer-Assisted Latin Teaching at the University of the Western Cape. The annual Latin Reading Competition for pupils in Standards 9 and 10 was held at Groote Schuur High School on 29 April 1981. Thirty-three contestants from eight schools participated. Their efforts were commended by the adjudicators, Dr Bruwer, Mrs Mezzabotta, Mrs De Vries and Mr R Whiteford. ${ }^{46}$ On 13 May 1981, Mr D Guerin gave a slide-show on 'The archaeology of Roman Britain', and on 31 July 1981, Prof C Foss (University of Boston, Mass.) spoke on 'The transformation of the Classical city'.

On 12 August 1981 a 'Shipwreck debate' took place at Jan van Riebeeck High School, in which 34 contestants from Standards 6-8 from 12 schools impersonated 'shipwrecked' Greek or Roman historical or mythological characters. The audience of 300 'pirates', chaired by the 'chief pirates' Miss C Liebenberg, Prof Conradie and a UCT student, Miss Susan Gordon, judged the pleas of the

\footnotetext{
43 De Villiers 1983.

44 Mezzabotta and Claassen 1981:40-41; Gordon 1981.

45 Mezzabotta and Claassen 1981:39.

46 Mezzabotta and Claassen 1981:39-40.
} 
'castaways' and awarded book prizes to the four who presented the most convincing argument for their survival. The function ranked among the most successful school projects ever undertaken. The enthusiastic audience went away with positive impressions of the Graeco-Roman world and Latin studies. The function was excellently organised by Dr Kathy Coleman and other members of the regional committee. ${ }^{47}$

At the AGM on 29 August 1981 at Stellenbosch, the following committee was elected: Mrs Mezzabotta (C), Dr Van Stekelenberg (VC), Dr Coleman (S-T), Mrs B Gibson (Schools' Secretary), Dr Atkinson, Mrs Claassen, Mrs S Thom, Misses C O’Dowd and Gordon, Messrs A Hull, F Pauw and K Richardson (AM). Dr P Wickins (Economic History, UCT) gave a talk on 'Edward Gibbon, historian' and Prof Smuts, who was retiring at the end of the year, presented a slide-show in Afrikaans and English on the motifs and symbolism of Early Christian art entitled 'Ou gestaltes, nuwe inhoude'. At the close, Prof Baumbach read a tribute to Prof Smuts in Latin. ${ }^{48}$

Two other events involved local classicists. On 24 November 1981, Prof Frank Goodyear (Bedford College, London), who was visiting UCT, Stellenbosch and the University of the Western Cape to conduct seminars, gave a talk on 'Fakes and forgeries in ancient literature'. Then, on 14 December 1981, a discussion on 'Classical civilisation in the schools' was led by Dr Michael Apthorp (University of Queensland), who shared his experience as examiner for Matriculation Classical Studies which had become popular in Australian schools. ${ }^{49}$

A Teachers' Meeting on 3 February 1982 at the Teachers' Centre, Mowbray, was attended by 30 school, university and student teachers. For the first time the workshop lasted a full day. The morning sessions consisted of an evaluation of the experiment of the internal Senior Certificate examination and an outline of the modifications made to the projected Latin syllabus, presented by $\mathrm{Mr}$ J S Labuschagne (Principal Education Planner, Humanities, Cape Province), and a discussion of the difficulties encountered by teachers of Classics, chaired by Prof A H R E Paap. The afternoon sessions were occupied by talks on the teaching of background study by Mrs J-M Claassen and Miss S Armstrong, and a discussion, conducted by Mrs Mezzabotta, on the possibility of introducing Classical Civilisation as a matriculation subject in South African schools..$^{50}$ As a result of the deliberations, several actions were embarked upon. A subcommittee was set up to collect visual-aid material on the background topics. Another subcommittee, tasked

\footnotetext{
47 Mezzabotta and Claassen 1981:40; Mezzabotta 1983:39.

48 Mezzabotta and Claassen 1981:41-42, with the tribute on p. 43; Mezzabotta 1983:40-41. See also Baumbach 1983.

49 Mezzabotta 1983:39.

50 Mezzabotta 1983:39.
} 
with investigating the desirability of introducing Classical Civilisation as a matriculation subject, reported in June that teachers were still opposed to the idea, since it was felt that the position of Latin itself would be undermined; more attention to Classical culture should be incorporated in the proposed new Latin syllabus. Teachers of Latin were urged to visit the Std 5 classes of neighbouring primary schools. Some university lecturers visited Coloured primary schools and Mrs Claassen circulated a memorandum on how to conduct such visits. A list was compiled of arguments that could be used to persuade pupils and their parents of the value of Latin. ${ }^{51}$

To celebrate the bimillennium of Vergil's death, UCT students, on 26 February 1982, read selections in Latin and English from the Aeneid, Books 1-6; Stellenbosch students, on 4 May, enacted scenes from N A Blanckenberg's Afrikaans version of the Aeneid..$^{2}$ On 28 April 1982 the annual Latin Reading Competition for Std 9 and 10 pupils took place at the Sans Souci High School, Newlands. Thirty-one contestants from eight schools participated. ${ }^{53}$ The next meeting of the branch, on 14 May 1982 at the University of Cape Town, was attended by about 100 people. To mark the International Year of the Aged, two lectures were presented: 'Life expectancy in the ancient world' by Prof J Atkinson, and, following a buffet supper, 'Delos — the island which outlawed death (with slides)' by Mr R Smith. ${ }^{54}$ The biennial Ludi Romani for Std 6-8 pupils took place on 11 August 1982 at St Cyprian's School, Oranjezicht. Schools presented dramatised versions of a Greek or Roman myth, in English or Afrikaans. ${ }^{55}$

\section{2. $\quad$ Fifteenth CASA Conference, 18-21 January 1983, Pretoria}

\subsection{Conference proceedings}

The First Business Meeting, held on 18 January 1983, was attended by 43 delegates, who were welcomed by the Chairperson, Prof Kriel. Delegates stood in silence in remembrance of the late Proff Farrer and Magnus Henderson. The Patron of CASA, Chief Justice P J Rabie, was congratulated on being awarded an honorary doctorate in Law by the University of Stellenbosch in December 1982.

Under matters arising from the previous conference, Prof Bruwer, who had given testimony to the Hoexter Commission on behalf of the Association, tabled a report on the Latin component of the LL.B course. There had been no feed-back

\footnotetext{
51 Mezzabotta 1983:40.

52 Mezzabotta 1983:40.

53 Mezzabotta 1983:40.

$54 \quad$ S to Executive, 22 July 1982, 2, §3.4; Mezzabotta 1983:39.

55 Mezzabotta 1983:40.
} 
from the co-opted members, since there had been no developments. However, in September 1981 a Unisa student was admitted to the Natal Bar with only Latin Special, and a year later, a student of the University of the Witwatersrand, M A Friedgut, applied for admission to the Transvaal Bar. Despite being opposed by the Transvaal Bar, and the presiding judges, Judge President W J Boshoff and Justices $\mathrm{H} \mathrm{P}$ van Dyk and H C Nicholas, reserving judgement sine die, two of the judges, Boshoff and Van Dyk, admitted another applicant, R C van Deventer, also without Latin I, to the Bar in December 1982. In view of these developments, it was decided that the committee and its co-opted members would be disbanded and that more could be achieved by the departments within their own universities. ${ }^{56}$

The Secretary, on behalf of the Executive, also reported that only the Western Cape and Transvaal Branches had submitted reports on their activities during 1981-1982. Members were informed that the Eastern Cape Branch had ceased to function, but that the Executive had thanked Drs Matier and Lewis for what they were doing in the interests of Classics. ${ }^{57}$ Then regarding membership of FIEC, the Executive proposed that for easier administration all correspondence should be addressed to the Secretary rather than to the permanent representative, Prof Hendrickx. The next meetings of FIEC were scheduled for 1984 in Dublin and 1989 in Pisa. Prof Saddington presented an account of his attendance of the congress in Finland, where he represented the Classical Association of Central Africa. ${ }^{58}$

The Chairperson proposed the following schedule for future conferences and colloquia: 1984 Colloquium (RAU), 1985 Conference (Rhodes), 1986 Colloquium (Pietermaritzburg), 1987 Conference (Stellenbosch). The theme for the next Colloquium would be 'Teaching Latin and Greek as literature' and the Colloquium Chairperson would be Prof Henderson..$^{59} \mathrm{He}$ also reported that the possibilities of the planned involvement with the Canadian academic centre in Rome had been exhausted. It was decided that he continue negotiations with Prof Hermansen. ${ }^{60}$

The Chairperson then delivered his report. Membership of CASA stood at 302 full members, 7 life-members and 5 honorary members. Members of the Executive had relied on 'meetings by correspondence' since live meetings had become too costly. All issues were dealt with by correspondence to and from the members of the Executive. The Colloquium had been a great success, and thanks were due to the organiser, Prof Atkinson, and to the initiator of the idea, Prof

\footnotetext{
56 Minutes of First Business Meeting, 18 January, 1983, item 6.1.

57 Minutes of First Business Meeting, item 6.2.

58 Minutes of First Business Meeting, item 6.3.

59 Minutes of First Business Meeting, item 6.4.

60 Minutes of First Business Meeting, item 6.5.
} 
Bruwer. On behalf of the Association, a strong plea was lodged by cablegram and letter against the proposed closing of the Classics Department at Bedford College, University of London. British colleagues expressed great appreciation for this gesture. Prof Kriel suggested that the possibility of a session for short communiqués by Honours and MA students at the next conference be considered. ${ }^{61}$

Approval of the financial report, tabled by the Chairperson in the absence of the Treasurer, was deferred to the Second Business Meeting. ${ }^{62}$ This was followed by the report on Acta Classica, tabled by Prof Naudé. He informed the meeting that the publication of the journal, which for 25 years, from Volume I, had been in the hands of A A Balkema, was now to be undertaken by the Assocation itself. Henceforth, from Volume XXV (1982), the journal would be printed by V \& R Printing Works in Pretoria and distributed by the Department of Latin at the University of Pretoria. The financial position of Acta Classica remained unfavourable. To solve the problem of the accumulation of unsold earlier volumes, it was resolved to bring these to the attention of members by placing advertisements in Acta Classica and Akroterion and including a note with the accounts sent to members. ${ }^{63}$

The report of Akroterion was tabled by Prof Conradie on behalf of Prof Smuts. Prof Conradie explained that the Editorial Board had asked Prof Smuts, who had retired, to continue as editor. The meeting approved a grant of R650 and R750 for 1983 and 1984 respectively. ${ }^{64}$

The chairperson of the Subcommittee for Latin at School, Prof Bruwer, expressed her gratitude to the Human Sciences Research Council for the financial grant which enabled her to carry out the research in Pretoria in 1981. The information and comments of teachers on inter alia syllabi, examination and textbooks which had been gathered by the HSRC as part of the Latin Project, had guided and influenced the Study Committee of the Cape Education Department in the design of a new syllabus for Latin. Mr B P Weidemann, Head Researcher at the HSRC, then reported on the progress of the project, which had, however, not yet reached a stage where recommendations could be released. A lively discussion followed..$^{65}$

The Chairperson reported on behalf of Prof Atkinson that the Subcommittee for Overseas Visitors could not really do more than disseminate information

\footnotetext{
${ }_{61}$ Minutes of First Business Meeting, item 7.1.

62 Minutes of First Business Meeting, item 7.2

63 Minutes of First Business Meeting, item 7.3.

${ }_{64}$ Minutes of First Business Meeting, item 7.4.

65 Minutes of First Business Meeting, item 7.5.
} 
concerning possible visitors, who should be invited by individual departments. His proposal that the subcommittee be dissolved was accepted. ${ }^{66}$

Prof De Wet, chairperson of the Subcommittee for Classical Culture at School, tabled an interim report in which he noted both enthusiastic support and opposition. ${ }^{67}$ The new Latin syllabus would probably incorporate a larger portion of classical culture; the matter could not be pursued further until this syllabus and the report of the HSRC on the European languages (French, German and Latin) appeared.$^{68}$

Notice was given of the following motions affecting the constitution:

1. that in the light of increasing inflation, life-long membership (Constitution 4(a)(i)) would be abolished, although present members would retain their privileges;

2. that student membership subscriptions were to be increased from R2 to $\mathrm{R} 4$, and the option of prepaid, three-year membership discontinued; the subscription for Associate Members was raised to R7;

3. that the office of Additional Member of the Executive was to be abolished and replaced by a Colloquium Chairperson, who would organise the biennial Colloquium. ${ }^{69}$

At the Second Business Meeting, on 20 January 1983, the following changes to the constitution were approved: life-membership was abolished, although existing lifemembers were to retain their privileges; the Additional Member was to be renamed Colloquium Chairperson to serve on the Executive with the colloquium as portfolio; the student membership fee was raised from R2 to R4 and the option to pay for three years in advance was abolished $;^{70}$ and membership fees were to be determined at the conference for the following two years. ${ }^{71}$ Other motions not affecting the constitution were (1) to bring the existence, activities, objectives and value of CASA and its regional branches, as well as Acta Classica and Akroterion, to the attention of all schools and teachers concerned with teaching Latin; ${ }^{72}$ and (2) to co-opt a member to the Executive to trace all teachers of Latin and Greek with a view to enrolling them as members and to advise the Executive as well as the executives of regional branches of suitable ways to involve teachers in the

See Minutes of First Business Meeting, 20 January 1981.

He referred to his article (1981) and that of Murgatroyd (1982).

68 Minutes of First Business Meeting, item 7.7.

69 Minutes of First Business Meeting, item 7.8.

70 Minutes of First Business Meeting, item 8.1.

71 Minutes of Second Business Meeting, 20 January 1983, item 2.2.

72 Minutes of Second Business Meeting, item 3.1 
activities of the Association and assist teachers as much as possible in the interests of Latin and Greek. Motion (1) was referred to the Executive and motion (2) was carried, with the amendment that the Executive should consider the possibility of appointing a professional PRO to advance the interests of the Association. ${ }^{73}$ The theme of the next conference was to be 'Modern Theory of Literature and Ancient Texts'. ${ }^{74}$

The meeting then turned to the appointment of the various standing committees. It was decided that the list of collaborators to the Editorial Committee of Acta Classica be discontinued and that the Editorial Committee be empowered (in collaboration with the Executive) to co-opt members, preferably from universities not represented on the Editorial Committee. The following were appointed to the Editorial Committee: Prof Gonin (Managing Editor), Prof Naudé (Treasurer), Dr Scholtemeier (Editorial Secretary), Proff Kriel and VogelWeidemann (ex officio as CASA Chair) (Additional Members). Prof Gonin expressed his appreciation that Acta Classica 24 (1981) had been dedicated to him, and announced that he would be retiring as Managing Editor at the end of $1983 .{ }^{75} \mathrm{It}$ was decided that the Editorial Committee, in collaboration with the Executive, should appoint one of its members as his successor. ${ }^{76}$

The term of office of the Committee for Classical Culture at school was extended for another two years. The members were: Prof De Wet (Chair) and one repesentative from each province, namely Mrs Claassen (Cape), Prof Henderson (Transvaal), Mr Van Ryneveld (Orange Free State). ${ }^{77}$ The Committee for Latin at School was also to remain the same for the next two years: Prof Bruwer (Chair), Proff De Wet, C A J Griesel, Kriel and Smuts. ${ }^{78}$ Prof Kriel was requested to continue to chair the Committee for an academic centre in Rome. ${ }^{79}$

The new Executive was then elected: Prof Baumbach (C), Prof De Wet (VC), Dr Matier (S), Dr Whitaker (T) and Prof Henderson (Colloquium Organiser). To comply with the provisions of the constitution regarding universities not represented on the Executive, heads of departments or their representatives were to be regarded as appointed to liaise with the Executive. ${ }^{80}$

The following motions of thanks were carried unanimously: to the Principal for the delightful reception on 18 January, as well as for the hospitality and

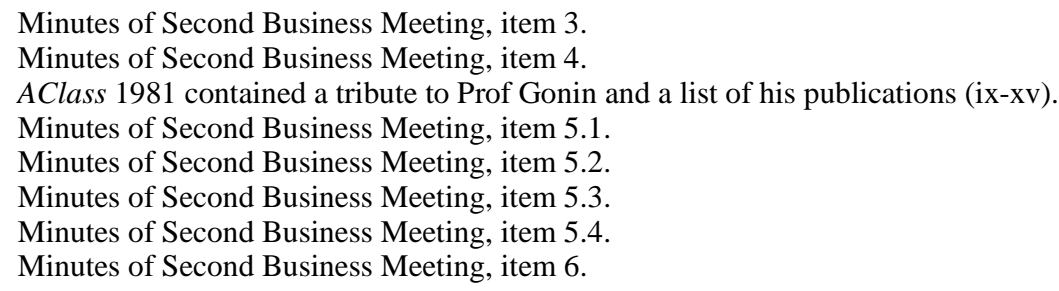


facilities provided by the University (Prof Baumbach); to Prof Kriel and the academic and administrative staff of the Departments of Greek and Latin for their excellent organisation, hospitality and helpfulness (Dr Chapman); to $\mathrm{Mr} \mathrm{De}$ Villiers and the Executive of the Transvaal Branch of CASA for the pleasant reception on 19 January, and the Longman's Group for sponsoring the reception and arranging an interesting exhibition of books on the Classics (Prof Naudé); and to all the speakers for their contributions (Prof Gonin). ${ }^{81}$

Under 'General' the following information was communicated to the meeting:

1. Speakers were invited to offer their papers for publication in Acta Classica; such papers would, as for all papers, be subject to the journal's refereeing processs; in preparing their manuscripts, authors were to follow the 'Guide to Contributors' published on the back page of Acta Classica.

2. Prof Claudio di Palma of Florence, a specialist on Etruscology, had indicated his willingness to lecture in South Africa; interested universities were to contact Prof Kriel.

3. Prof Baumbach was to read a paper at the next conference of FIEC and was requested to represent CASA.

4. Prof De Kock requested the Executive to consider re-introducing the arrangement of appointing specific persons to open discussion on each paper.

5. It was suggested that speakers should provide copies of their papers beforehand.

6. There was a request from the floor that a list be compiled with the names and addresses of all available Latin teachers. The request was referred to the proposed PRO.

7. An urgent appeal was made to all departments of Latin or Greek to maintain contact with all their former students who were teaching Latin. $^{82}$

During the conference 15 papers were read. ${ }^{83}$

Minutes of Second Business Meeting, item 7.

Minutes of Second Business Meeting, item 8.

83 Programme, 18-21 January 1983. 


\section{BIBLIOGRAPHY}

Atkinson, J 1981. Colloquium 1982. Akroterion 26.4:34-36.

Baumbach, L 1983. Prof Frans Smuts: 'n Huldeblyk. Akroterion 28.3 \& 4:61-62.

Claassen, J-M and Atkinson, J 2012. Reviews of Lambert 2011. Acta Classica 55:172-178; 178-182.

De Villiers, J J 1983. The Classical Association of South Africa: Chairman's report. Akroterion $28.1 \& 2: 37-38$.

De Wet, B X 1981. Is there a place for Classical Civilisation at school? Akroterion $26.1 \& 2: 1-15$.

Gordon, S 1981. University of Cape Town: Homeric reading marathon. Akroterion $26.1 \& 2: 67-68$.

Hall, R F 1982. Virgil and English literature. Akroterion 27.2:40-52.

Hasse, P 1982. Publications received in exchange for Acta Classica. AClass 25:149-156.

Henderson, W J 2004. The Classical Association of South Africa: April 1956January 1961. Akroterion 49:89-109.

Henderson, W J 2005. The Classical Association of South Africa: February 1961July 1966. Akroterion 50:109-123.

Henderson, W J 2006. The Classical Association of South Africa: July 1966January 1971. Akroterion 51:135-156.

Henderson, W J 2007. The Classical Association of South Africa: January 1971 January 1975. Akroterion 52:99-114.

Henderson, W J 2008. The Classical Association of South Africa: January 1975 January 1979. Akroterion 53:99-114.

Henderson, W J 2010. The Classical Association of South Africa: February 1979 January 1981. Akroterion 55:87-115.

Henderson, W J 2013. The Classical Association of South Africa, 1908-1956. Akroterion 58:123-150.

Hendrickx, B 1981. Die K.V.S.A. en die F.I.E.C. Akroterion 26.4:37-38.

Lambert, M 2011. The Classics and South African Identities. London: Bristol Classical Press.

Mezzabotta, M 1983. Western Cape Branch. Akroterion 28.1 \& 2:38-41.

Mezzabotta, M and Claassen, J-M 1981. Activities of the Western Cape Branch of the Classical Association. Akroterion 26.4:39-42.

Murgatroyd, P 1982. Classical civilisation at school - some cautions. Akroterion 27:22-25.

Ronca, I 1982. The World Congress on Virgil: 19-24 September 1981. Akroterion 27.1:4-13. 
Van Stekelenberg, A V 1982. Latin in the curriculum of legal studies in SA: recent developments. Akroterion 27.3 \& 4:89, 161. 